\title{
Some Issues of Japanese Speech-Language-Hearing Therapy Education
}

\author{
Kyoko litaka ${ }^{a}$ Kiyoshi Otomo ${ }^{b}$ \\ ${ }^{a}$ Sophia Linguistic Institute for International Communication, and b Tokyo Gakugei University, Tokyo, Japan
}

\section{Key Words}

Speech-language-hearing therapy education, Japan • Employment disadvantages - First language acquisition • Second language acquisition - Language development, early intervention

\begin{abstract}
Recent trends in Japanese speech-language-hearing (SLH) therapy education are reported. The rapid growth of educational institutions has continued since our last report. The educational curriculum was established by the 1997 certification of Japanese SLH therapists, and is strictly applied to educating both college/university and vocational school students. Over 1,000 students annually become registered SLH therapists, of whom nearly $70 \%$ are under the age of 39 years. More therapists are employed full time to serve the adult population, while a limited number of therapists are fully employed to provide services to children. As a member of the economically more advanced nations, Japan receives assistance from foreign workers coming from economically less developed nations. Their children face the difficult tasks of learning both their mother tongue and Japanese. There is a strong need for our profession to assist the early language acquisition of these children because their cognitive and
\end{abstract}

\section{KARGER}

Fax +4161306 1234

E-Mail karger@karger.ch

www.karger.com
(C) 2010 S. Karger AG, Basel

$1021-7762 / 10 / 0625-0228 \$ 26.00 / 0$

Accessible online at: www.karger.com/fpl personal development will be greatly influenced by adequate language acquisition. An appeal is made to our colleagues for sharing the mutual tasks of bringing about better linguistic and communicative development in those educationally disadvantaged children.

Copyright $\odot 2010$ S. Karger AG, Basel

\section{Present Japanese Speech-Language-Hearing Therapy Education}

The present condition of Japanese speech-languagehearing (SLH) therapy education reveals a similar picture as in 2002 [1]. In Japan, the rapid growth of institutions for SLH therapy education continues. As of May 2009, there were 19 colleges and universities and 46 vocational schools which strictly adhere to the curriculum of 2,400 h established by the 1997 Japanese law for speech therapists. There are only 3 universities with liberal arts curricula which adopt the subject of speech therapy, but they do not strictly keep to the 2,400-hour program. Although this provision was made at the time of legalization in 1997, maintaining the latter program is becoming extremely difficult. In addition, during the 5-year transitional period, the teachers for the children with speech 


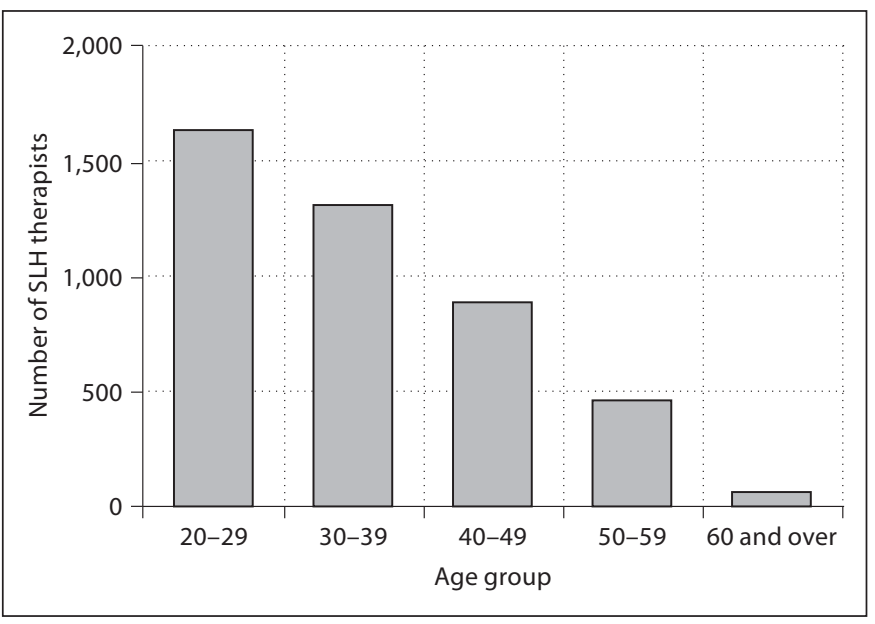

Fig. 1. Age classification of Japanese SLH therapists.

and hearing difficulties in public schools were allowed to take additional courses in order to participate in the national examination for SLH therapists. However, this provisional period is over. Now there is little linkage of the educational curriculum between SLH therapists and teachers for special education needs [2].

\section{Characteristics of Japanese SLH Therapists as a Group}

Since 1998, about 1,000 graduates have annually passed the national examination for Japanese SLH therapists. As of April 2009, 14,329 held the national license [3]. According to a survey by the Japanese Association of Speech-Language-Hearing Therapists [4], the gender ratio in 2003 had been $18 \%$ male $(n=793)$ to $82 \%$ female $(\mathrm{n}=3,548)$. Then, the younger members aged under 39 years comprised nearly $70 \%$ of all SLH therapists and the percentage became smaller with higher age (fig. 1). A similar condition, showing greater numbers in the younger groups, might be found in 2010 .

\section{Employment Status}

The previous survey [4] reports that $78 \%$ of the registered SLH therapists for adults were employed full time. In comparison, SLH therapists for children were employed mainly on a part-time basis, reflecting the fact that relatively few institutions can employ full-time registered SLH therapists for children. The following result shows the numbers of registered SLH therapists by area of service provision (multiple answers possible). This might have inflated the trend but still shows services are available more for adults than for children (table 1).
Table 1. Number of SLH therapists by area of service provision (multiple answers possible)

\begin{tabular}{lrl}
\hline & Number & Percentage \\
\hline Adult language and cognition & 2,860 & 66 \\
Speech and voice & 2,622 & 60 \\
Feeding and swallowing & 2,661 & 61 \\
Children's language and cognition & 1,648 & 38 \\
Hearing & 833 & 19 \\
Unknown & 485 & 11 \\
\hline
\end{tabular}

Table 2. Employment settings for part-time SLH therapists for children $(\mathrm{n}=120)$

\begin{tabular}{lcc}
\hline & Number & Percentage \\
\hline Municipal health center & 48 & 40 \\
Center for training the handicapped & 32 & 27 \\
Hospital & 16 & 13 \\
Nursery school & 13 & 11 \\
Special needs education in public school & 3 & 2 \\
Others & 8 & 7 \\
\hline
\end{tabular}

\section{SLH Therapists for Children in Japan}

The apparent shortage of SLH therapists for children might reflect the nature of the clinical practicum defined by the law for Japanese SLH therapists. The curriculum of Japanese SLH therapists was made with stronger emphasis on rehabilitation. As a result, two-thirds of the clinical practicum hours must be taken in medical settings. However, it is difficult to find enough full-time SLH therapists in medical settings who could supervise the therapy of children. A survey was made [5] by 120 SLH therapists working with children on a part-time basis by using Internet communication, as shown in table 2 .

In addition, when asked about the areas of service provided by these part-time SLH therapists for children, the multiple answers were as shown in table 3 . In spite of a need for their services, the SLH therapists were underpaid because of their part-time employment status.

Public health examination shown in table 3 is conducted to evaluate the overall development of all children at the ages of 4, 18 and 36 months by the local public health centers based on a national law. Those parents whose children are found to have developmental delay need guidance for necessary care. 
Table 3. Areas of service provided by part-time SLH therapists for children (multiple choice)

\begin{tabular}{ll}
\hline & Percentage \\
\hline Consultation & 63 \\
Evaluation & 56 \\
Individual therapy & 48 \\
Follow-up consultation with parents $^{1}$ & 33 \\
Therapeutic training & 17 \\
Home visitation $^{\text {Group therapy }}$ & 10 \\
Public health examination $^{1}$ & 7 \\
Others & 4 \\
\hline
\end{tabular}

${ }^{1}$ Follow-up consultation after public health examination.

There are some questions raised by the results of this survey [5]. Part-time SLH therapists were employed for consultations with parents and nursery school teachers about delayed speech and language development. This service requires a sound background in child development. In addition, considerable clinical training is necessary under experienced supervisors. However, there is a shortage of such supervisors.

There is also an increased need for assisting children with learning disabilities. In order to effectively cooperate with the special education teachers, the SLH therapists need to have adequate experience in such areas as reading and writing development. However, the present Japanese curriculum lays greater emphasis on a biomedical background.

\section{Continuing Education Program}

To meet the needs of younger therapists, the Japanese Association for Speech-Language-Hearing Therapists now advocates a continuing education program, encouraging the members to participate in the workshops held in various academic meetings [6]. Each participant is given certain points depending on the nature of and time spent in his/her continual education. The contents of this program are similar to those practiced by the American Speech-Language-Hearing Association. The education guidelines by the IALP (International Association of Logopedics and Phoniatrics) should also be helpful in conducting these activities.

\section{Challenging Issues for Professions in Communication Disorders}

\section{Educational Needs of Children of Foreign Workers}

In this section, the urgent educational needs of children whose parents have come from abroad to work in Japan will be addressed. Japan is increasingly dependent on the presence of foreign workers in all spheres: economic and social. The number of foreign residents, especially from South America, increased after the change of the Japanese immigration policy in 1990 [7]. The policy stated that the descendants of Japanese emigrants to South American countries were allowed to come back to Japan under less strict regulations than other foreigners. As a result, the number of foreign residents rapidly increased and surpassed 2 million. An estimated 70,000 non-Japanese children attend public schools, including those who have not been well prepared for studying academic subjects in the Japanese language.

According to the official report by the Japanese Ministry of Education, Culture, Sports, Science and Technology [8], the largest population of foreign students needing special assistance to learn the Japanese language was Brazilian (70\%), followed by Spanish (14\%), Tagalog (6\%), Chinese (3\%) and others. Due to the recent global economic recession, these figures might have been modified while presenting the similarly urgent educational needs of those children whose parents lost their jobs. It may also be possible that these children do not attend school at all since some parents move from place to place in order to find jobs.

\section{Lack of Early Mother-Child Interaction}

The first concern is that children of foreign workers often fail to acquire sufficient mother tongue (L1) skills since their parents work long hours, which prevents mothers or caretakers from having early close interactions with the infants. Since early mother-child interaction is very important not only for providing the linguistic background, but also for helping him/her to establish a self-identity and develop cognitive abilities, the lack of such interaction has resulted in a poor proficiency in both L1 and second language (L2) among these children.

\section{Question of $L 1$ versus L2 Acquisition}

Although it is of utmost importance to acquire L1 [9, 10], and 'no language is regarded as superior to or more important than any other language', the child still needs 'to communicate on a daily basis' to learn to use the language of its present environment (L2) [11, p. 104]. We 
Table 4. Percentage of correct responses on Japanese vocabulary test by Brazilian preschoolers

\begin{tabular}{lllllll}
\hline $\begin{array}{l}\text { Academic } \\
\text { year }\end{array}$ & $\begin{array}{l}\text { Number of } \\
\text { children }\end{array}$ & $\begin{array}{l}\text { Japanese nursery } \\
\text { or kindergarten }\end{array}$ & $\begin{array}{l}\text { Brazilian } \\
\text { nursery }\end{array}$ & Home & $\begin{array}{l}\text { Home country } \\
\text { (Brazil) }\end{array}$ & Unknown \\
\hline 2004 & 65 & $87.4 \%$ & $19.0 \%$ & $33.5 \%$ & $44.5 \%$ & $44.7 \%$ \\
2005 & 108 & $82.2 \%$ & $20.2 \%$ & $35.0 \%$ & $2.0 \%$ & $66.3 \%$ \\
\hline
\end{tabular}

Table 5. Longitudinal results of the same vocabulary test administered to a Brazilian child in 2 years

\begin{tabular}{llll}
\hline & $\begin{array}{l}\text { 1st-grade } \\
\text { Japanese vocab- } \\
\text { ulary (2004) }\end{array}$ & $\begin{array}{l}\text { 3rd-grade } \\
\text { Japanese vocab- } \\
\text { ulary (2006) }\end{array}$ & $\begin{array}{l}\text { 3rd-grade } \\
\text { Portuguese } \\
\text { vocabulary }\end{array}$ \\
\hline Correct responses & $13 \%$ & $56 \%$ & $64 \%$ \\
\hline
\end{tabular}

know that acquiring the language (L2) used in the local society influences the success in making a living. The survey reports that those Brazilian workers who are successful in finding employment are those being proficient in the Japanese language [12].

\section{Effectiveness of Early Language Intervention}

The preschool environment appears to play an important role in assisting the child to acquire the vocabulary of L2 [13] (table 4). On the other hand, a child does not easily acquire both L1 and L2 even if it is placed in a Japanese-speaking school environment. A longitudinal study revealed that the third-grade child in table $5 \mathrm{im}$ proved his test scores from 13 to $56 \%$ in 2 years, slightly surpassing 50\% [14]. An important fact is that the percentage of correct responses in the child's native vocabulary at third grade was only $64 \%$. This shows that he was not proficient in either language. He could carry on a daily conversation after having been in a Japanese public school for 2 years. His Japanese classroom teacher assumed that he could understand everything. But this was not the case. In fact, he was often misunderstood as he was not able to follow the Japanese instructions in his class, and was assumed to be 'careless', or 'not paying attention to his teacher' $[14,15]$.

The statistics from 1993 to 2002 revealed that $86 \%$ of the remedial instructions for juvenile inmates were provided to individuals of Brazilian background [16]. Their average reading ability was equivalent to the level of kindergarten children. During their stay at the remedial in- stitution, each had 80 min of Japanese instructions, 4 days a week. They showed remarkable progress in that program. These youngsters were school 'dropouts' and did not have the opportunity to study according to their readiness to learn. When given the opportunity for learning, they eagerly studied and rapidly acquired the Japanese language. They obtained professional training and became responsible members of the society according to the report from the Kurihama Remedial Institution [16]. A similar report was presented at a symposium focusing on the communication problems of children of Brazilian foreign residents [17].

The previous reports emphasize how important early intervention is. With a lack of Japanese language skills and school readiness training prior to entering the first grade of primary school, these children simply could not understand the subjects well enough to follow the classroom activities. More tax money is required for their remedial training. Moreover, their self-image is badly damaged. If they were able to acquire adequate linguistic and social abilities, they could be better adjusted to school and community. They would have increased their self-confidence as young adults, utilizing their given abilities and talents to accomplish something worthy of acknowledgment and social recognition.

\section{Efforts of Japanese Communities to Meet the Needs of} Foreign Residents

During the serious economic recession, a council of 19 municipalities with a large concentration of foreign residents held an annual meeting in fall 2009 to exchange information and increase cooperation to improve the economical, social and educational conditions of those residents. Since 2001, this council has been organized to meet the needs of these foreign residents. The council has made a public appeal and presented common proposals to the national and local governments about the needs of these foreign workers and their families [18]. 
Roles Shared by Speech and Language Professions

Speech and language therapists also share important roles in consulting with the local board of education and school teachers regarding the special provision needs of those children with a limited linguistic proficiency. There is an urgent need for developing reliable assessment tools for speech and language skills [19]. Effective language intervention is only possible with adequate information about both L1 and L2 of these children. After 12 years of literacy work with linguistic minority groups in Nepal, Noriko Matsuura, a Japanese speech pathologist, reported that those who had successfully acquired L1 were better learners of L2 [20-22]. Her observations could apply to teaching Japanese as L2 to Brazilian children whose L1 is Portuguese.

In Japan, we hope to devise some multilingual assessment tools by adapting the recently published Language Communication Development Scale [23] to those children with different linguistic backgrounds. Kojima [24] and his coworkers published a bilingual handbook in Portuguese and Japanese with illustrations. We have made oral recordings of simple picture books for young children by a bilingual mother from Brazil. These recorded tapes are used by the preschool program for Brazilian children. To offer various ideas and resources, we have just published a teacher's guidebook for stimulating the linguistic and communicative development of foreign preschoolers in local communities. This aims to provide necessary information for conducting the preschool program for children with foreign parents [25].

\section{Concluding Remark}

As professionals for communication disorders, we have much to offer for the betterment of those individuals having difficulties due to organic, cultural and environmental factors. The current educational curriculum for Japanese SLH therapists including a clinical practicum needs to be reevaluated in order to meet the present needs, especially of children. The educational guidelines by the IALP Educational Committee for Logopedics should be very useful for this process. Let us meet the challenges of emerging issues in the 21st century in each of our countries.

\section{Acknowledgments}

We are grateful to the Japanese Association of Speech-Language-Hearing Therapists for permitting us to use their Web site and other bulletins. Gratitude goes to Ms. Mami Mitachi, Educational Facilitation Office, for her help in preparing the tables and figure for this report. Also we thank Dr. Robert Hayes for proofreading the manuscript.

\section{References}

1 Iitaka K: Japanese speech therapy (logopedics) education after presentation of the Educational Guideline in the 1995 IALP. Folia Phoniatr Logop 2002;54:75-78.

2 Iitaka K: Issues of Japanese speech therapy education considering the 1995 Guidelines of IALP. Folia Phoniatr Logop 2006;58:4147.

3 Medical Science Foundation: Annual report on the licensed Japanese speech-languagehearing therapists (in Japanese). Tokyo, Japanese Ministry of Health, Labor and Welfare, 2009.

4 Japanese Association of Speech-LanguageHearing Therapists (JAS): Data based on 2003 survey (in Japanese). JAS website, 2007.

5 Goto K, Nakagawa N, Tasaka K, Hosokawa J: A survey on working conditions of part-time Japanese SLH therapists for children (1) Regarding salary. The Proceedings of the 6th Convention of JAS, 2005:105 (in Japanese).

6 Japanese Association of Speech-LanguageHearing (JAS): Education (in Japanese). 2008.
7 Douglas M, Roberts G: Japan and Global Migration. Foreign Workers and the Advent of a Multicultural Society. Honolulu, University of Hawaii Press, 2003.

8 Yoshida T: The issues of education for children of foreign residents focusing on Southern Americans: a survey report on the foreign children and students needing assistance in Japanese language acquisition (in Japanese). 2009. http://www.mext.go.jp/b_ menu/houdou/19/08/07062955.htm.

9 UNESCO: First language first: communitybased literacy program for minority language context in Asia. Bangkok, UNESCO, 2003.

10 Turin M: A mother of mother tongue education. Nepali Times, April 7, 2007, p 13.

11 Jordaan H: Clinical intervention for bilingual children: an international survey. Folia Phoniatr Logop 2008;60:97-105.

12 Higuchi N: Teaching Japanese language should precede offering part-time jobs for the unemployed foreign workers from South America. Asahi Shimbun, May 16-17, 2009.
13 Miyajima T, Tsukihi H: The influence by employment and life style of parents upon school life of their children, Brazilian nursery, Japanese school, and family: report on the background of children's schooling among foreign families and the network for assisting their education (in Japanese). A scientific report on research granted by the Japanese Ministry of Education, Culture, Sports, Science and Technology, No. 16330109, 2007, pp 27-44.

14 Tsukihi H: Longitudinal studies of language abilities of Brazilian children in public school (in Japanese). A Symposium on language and communication development of children whose parents are foreign workers (in Japanese). Proceedings of the 45th Conference of the Association of Special Education, 2007.

15 Yamawaki K: Too many foreign kids falling through the cracks. International Herald Tribune/Asahi Shimbun, January 20-21, 2007. 
16 Editorial staff of Japanese Monthly Journal: Profile of a Japanese Instructor. A report of interviewing Mr. T. Sugito at Kurihama Remedial Institution for Youth. 2006, November, 22-23 (in Japanese).

17 Toida HH: Problems and tasks by Brazilian children in Japan (in Japanese). A Symposium on language and communication development of children whose parents are foreign workers. Proceedings of the 45th Conference of the Association of Special Education, 2007.

18 Council of Municipalities: The 21st annual report (in Japanese). Tokyo, Council of $\mathrm{Mu}$ nicipalities, 2008.
19 Multilingual Affairs Committee of IALP: Recommendations for working with bilingual children. Folia Phoniatr Logop 2006;58: 458-464.

20 Matsuura N: A baseline study of literature in the minority languages of Nepal. Sophia Linguistica 2006;54:17-65.

21 Matsuura N: Mother tongue story production workshop annual report: the MT Pipal Pustak Project. Paris, UNESCO, 2008, pp 14-24.

22 Yoshida K, Matsuura N, Iitaka K: A preliminary report on language education in multilingual societies utilizing reading materials in Nepal and Japan: annual report of the Sophia Linguistic Institute for International Communication (in Japanese). 2008, pp 22 92.
23 Otomo K, Hayashi A, Hashimoto S, Ikeda K, Kanno A: Language Communication Development Scale (in Japanese). Tokyo, Gakuensha, 2008.

24 Kojima T: PICOT communication book (Livreto de Communicação, 1a, Edição Illustrativa). 2008. http://homepage.mac.com/ aac_support.

25 Bureau of International Understanding Aichi Prefectural Government: A teacher's guidebook for assisting linguistic and communicative development of preschool children whose parents are foreign workers (in Japanese). Nagoya, Bureau of International Understanding Aichi Prefectural Government, 2009. 